\title{
LANDSCAPE ANALYSIS AND REGAIN FUNCTIONALITY OF GÜLISTAN GARDEN IN THE HISTORIC VAN CASTLE
}

\author{
Feran Aşur ${ }^{*}$, Şevket Alp ${ }^{1}$ \\ ${ }^{1 *}$ Department of Landscape Architecture, Faculty of Architecture-Design Yuzuncu Yll University, Van, Turkey; \\ "Corresponding author Feran Aşur, email: feranekasur@gmail.com; alp.sevket@gmail.com;
}

Received November 2019; Accepted December 2019; Published January 2020;

DOI: https://doi.org/10.31407/ijees10.108

\begin{abstract}
Located along the city shores of Van Lake in Turkey, the city of Van has hosted many civilizations, and historic and archaeological wealth and heritage. The landscape and environmental restoration project, which covers an area of approximately $5.000 \mathrm{~m}^{2}$ in the northeast of Van Castle supported by Van Governorship, was put into practice in 2006 under the name of "Gülistan Garden". The Gülistan Garden became a recreation area of local and foreign tourists visiting the castle and the old town until 2010. Although the garden is located in the first-degree archaeological site, it has lost its quality landscape image characteristic under negative environmental effects today due to lacking maintenance and repair works. The study aimed to reveal the cultural importance of landscape functionality for the city in today's historical sites by comparing the first years and the current status of the Gülistan Garden in terms of its visual landscape quality in the case of Van city. In the study, the landscape design project of Gülistan Garden was examined, the equipment elements, activity area, plant, and structural assets were taken into consideration, basic features in terms of quantity have been revealed. The first construction and current status visual landscape value were determined. Based on the analyses, two basic suggestions were developed for regaining the functionality of the area and the recovery of the visual value due to the low visual landscape quality and lost quality and maintain the sustainability of its landscape.
\end{abstract}

Keywords: The Gülistan Garden, Historical Landscapes, Regain Functionality, Van Castle 